\title{
Multiple visioning: new ways of constructing transnational spatial visions
}

\section{Wil Zonneveld}

OTB Research Institute for Housing, Urban and Mobility Studies, Delft University of Technology, PO Box 5030, 2600 GA Delft, The Netherlands; e-mail: w.zonneveld@otb.tudelft.nl

Received 1 July 2003; in revised form 15 May 2004

\begin{abstract}
In many parts of Europe, but also at the level of the European Union and the much higher level of the Council of Europe, the creation of spatial visions is now underway. However, these spatial visions often lack an essential ingredient of spatial planning, namely maps. This omission may seem paradoxical, because maps are essential for communicating ideas with a spatial dimension. The vast spatial and political complexities at transnational and European levels are addressed by elementary processes of visioning and mapmaking. Because maps are social constructs, no single, optimal map will exist. Transnational visioning therefore implies the creation of multiple maps and multiple visions.
\end{abstract}

\section{Introduction ${ }^{(1)}$}

When unravelling the spatial structure of Europe for the purpose of spatial planning, with all its analytic and political complexity, one can look back on about half a century of history. From the beginning, efforts to conceptualise Europe's spatial structure have clearly been a mixture of scientific analyses and political agendas. Concepts, particularly when accompanied by maps, have often led to political discussions, even controversies, because they convey perceptions of an area that are not universally accepted. This is the consequence of spatial concepts being constructs or images of existing realities (compare Harvey, 1969, page 19). Spatial planning concepts bring in another dimension, leading to considerable potential for conflicts. Such concepts present images of a desired spatial structure, so their normative content is even larger. At the cross-border and transnational levels it seems almost impossible to reach a broad consensus on spatial planning concepts, let alone maps, which in some respects constitute the pinnacle of conceptualisation.

The reason why we find hardly any planning maps at these levels is simply because maps, like spatial concepts in general, leave out certain characteristics and qualities while emphasising others. Maps construct the world, they do not reproduce it, and they therefore bear considerable power. Although cartographic visualisations can help overcome language barriers (Kunzmann, 1996), for these same reasons, producing images of a large-scale territory is a highly sensitive matter, especially when different countries and planning cultures are involved (Zonneveld, 2000). We have become aware of this sensitivity from efforts to arrive at spatial visions at the European or transnational level. The thorny nature of conceptualisation at this level is mirrored in the authorship of many of the documents that are produced. In fact, it is common practice at the transnational level for there to be no official 'author' at all. Although spatial planning concepts and their visual expression in the form of maps are ultimately the work of real-sometimes identifiable - men and women, no authors or planning subjects are mentioned. The most appropriate designation would be 'anonymous', as in music. 
In coming to terms with the extraordinary difficulties associated with European transnational visioning and mapmaking, it is necessary to accept and appreciate their highly political character. In this paper I aim to discuss critically the present state of mapmaking at the European/transnational level. In the first part I discuss the nature of planning and mapmaking. In the following section I discuss the constructed nature of maps, starting from the definition that a map images either the existing or the desired spatial structure of an area. The next four sections present examples of transnational and European trajectories of visioning. In the final section the various strands are drawn together and a new approach proposed: instead of striving for a single vision, the aim should be to develop an array of visions and maps, each unveiling a 'reality', or a desired future. Multiple visioning is also needed because the complex spatial reality of today cannot be approached using the current vocabulary of cartography. There is a need for a multiplicity of visual languages.

\section{Planning and mapmaking}

In a recent paper in the Journal of the American Planning Association, Van Eeten and Roe (2000) attack the Dutch Green Heart policy in an unprecedented way. Their main argument is that the spatial planning concept of the Green Heart (a relatively open area within a ring of cities called the Randstad) is fiction but nevertheless immune to criticism. In their persuasive paper Van Eeten and Roe assert that alternatives to this Green Heart policy are not given a fair chance. In trying to explain the hegemonic position of the Green Heart they point to the communicative power such a metaphor can have. Of course, this was precisely the reason why the Green Heart metaphor was invented in the first place (Faludi and Van der Valk, 1994)! Van Eeten and Roe conclude that planning must renounce that which has proven to be the most powerful weapon in planning discourse, namely mapping. Certainly not ill disposed towards using metaphors for their own rhetorical purposes, they reject any planning strategy which uses maps as an "iconographic gaze" (2000, page 64). Following Wood's wellknown book The Power of Maps (1992), Van Eeten and Roe conclude that maps are by nature fictional if for no other reason than that they exclude certain details of what is present 'on the ground'. Indeed, maps are useful and powerful precisely because they leave out some details (page 64). Oddly, because Van Eeten and Roe assert that the alternatives to the present Green Heart policy which have been put forward all use mapping strategies, "there is no mapping our way out of the deadlock ... . One way out of the controversy is to adopt planning approaches that depend much less directly on maps and cartographic imaging" (page 65).

This conclusion is interesting: let us plan but, please, without maps. However, Van Eeten and Roe are not very clear about the maps to which they refer. When the Green Heart concept was originally proposed in the 1950s, its visualisation was quite simple and therefore very powerful. We can see the graphic representation of this area becoming rather complex at the end of the 1980s and early 1990s. This was the period when the Green Heart became part of a strategy to present this area as an asset of an urban region involved in the increasing international competition between regions in Europe. To present the Green Heart as just a green belt was considered insufficient. Its endogenous and potential qualities had to be (re)defined. The national government started a planning exercise leading to an array of maps, each visualising certain characteristics of the area. Behind the scenes and the pages of the final planning document (Stuurgroep Groene Hart, 1992), the power relationships worked themselves out. The exercise was set up as a negotiation process between the representatives of central and provincial government. These in their turn stand for the interests of other stakeholders, agricultural organisations, or nature and landscape conservationists, 
for instance. The maps that were being produced reflect partial interests and different perceptions of space. Looking at the Green Heart from an agricultural perspective we can see that the various subspaces particularly suited to certain forms of agriculture stand out (and are mapped!) Similarly, looking at the Green Heart from a nature conservation perspective leads to a mapping of areas reflecting perceptions of their ecological values and their spatial relations. The final 'spatial vision' map in its complicated, multilayered visual language (see figure 1, over) reflects the complexities of the planning process, the different conceptions and constructs of space, and the power relationships which were being established. Nevertheless, we are dealing here with subdiscourses of the dominant discourse, namely to prevent the Green Heart becoming part of the built-up area of the Randstad.

It would, however, be far too simple to explain the hegemonic position of this discourse as the result of a cunning exercise in mapping. It is important to look behind maps and behind the metaphors to see what mechanisms are at work. The Green Heart became politically accepted in the late 1950s and early 1960s, because the idea of keeping this area open concurred with the interests of the agricultural sector, which claimed that such an important agricultural region should not fall victim to haphazard urbanisation. As soon as the economic basis of the agricultural sector started to crumble in the 1980s and 1990s the protagonists of alternative discourses seized their opportunity. But in the meantime the idea of preserving a Green Heart in the middle of the Randstad could count on the political support of other powerful interests such as nature and landscape conservation. And, indeed, maps and other images were used in the struggle for hegemony.

Does the proposal of Van Eeten and Roe make sense? They seem to be saying that, because maps are particularly suited for presenting 'fictions' and are very effective in hegemonic discourse, one should get rid of them altogether. But simplification, stereotyping, and hegemonic discourse could also be reached through mere verbal language. Directing the arrows at the societal groups using maps and metaphors makes far more sense. And, on top of that, is the making of spatial plans possible without making maps? Alexander, well acquainted with Dutch planning and familiar with the Dutch planners' predilection for spatial imagery, strongly rejects the idea, but not because he wants to protect the Dutch style of spatial planning or the protagonists of the Randstad/Green Heart 'doctrine'. Alexander (2001, page 98) asserts that "some form of graphic representation ... is essential for communicating any ideas that have a spatial dimension, as planning concepts and doctrines must have; and ... the fact that all metaphors are essentially fictions in their relation to reality in no way diminishes their usefulness in conceptualising and communicating planning ideas." Similarly, Faludi (1996, page 96) argues that what sets planning apart from other policy fields is its focus on spatial dispositions and activity patterns, and that space is best depicted visually. "The most common way in which this is articulated is by means of a plan in the classic sense: a map" (page 96). Thus, planning involves - or should involve, because at the transnational and European level this proves to be very hard-drawing maps.

Faludi (1996, page 94) relates imaging, or figuring, to framing. Knowledge is not a mirror image of reality, especially when problems demand a collective response; problems are never objectively given, but socially constructed "through frames in which facts, values, theories and interests are integrated" (Rein and Schön, 1986, page 4). Following Rein and Schön, Faludi emphasises naming as the first step towards the formulation of frames or frame-laden discourse. This is shown by the example of calling a large predominantly agricultural area in the highly urbanised western part of the Netherlands a 'Green Heart'. A more recent example is the 
renaming of the Randstad as the Deltametropolis in order to claim global city status for this polycentric urban region (Salet, 2003, page 182). At the transnational level, naming is often more subtle, because striking names and metaphors more often stir up controversy than act as a unifying concept. This was the case with such metaphors as
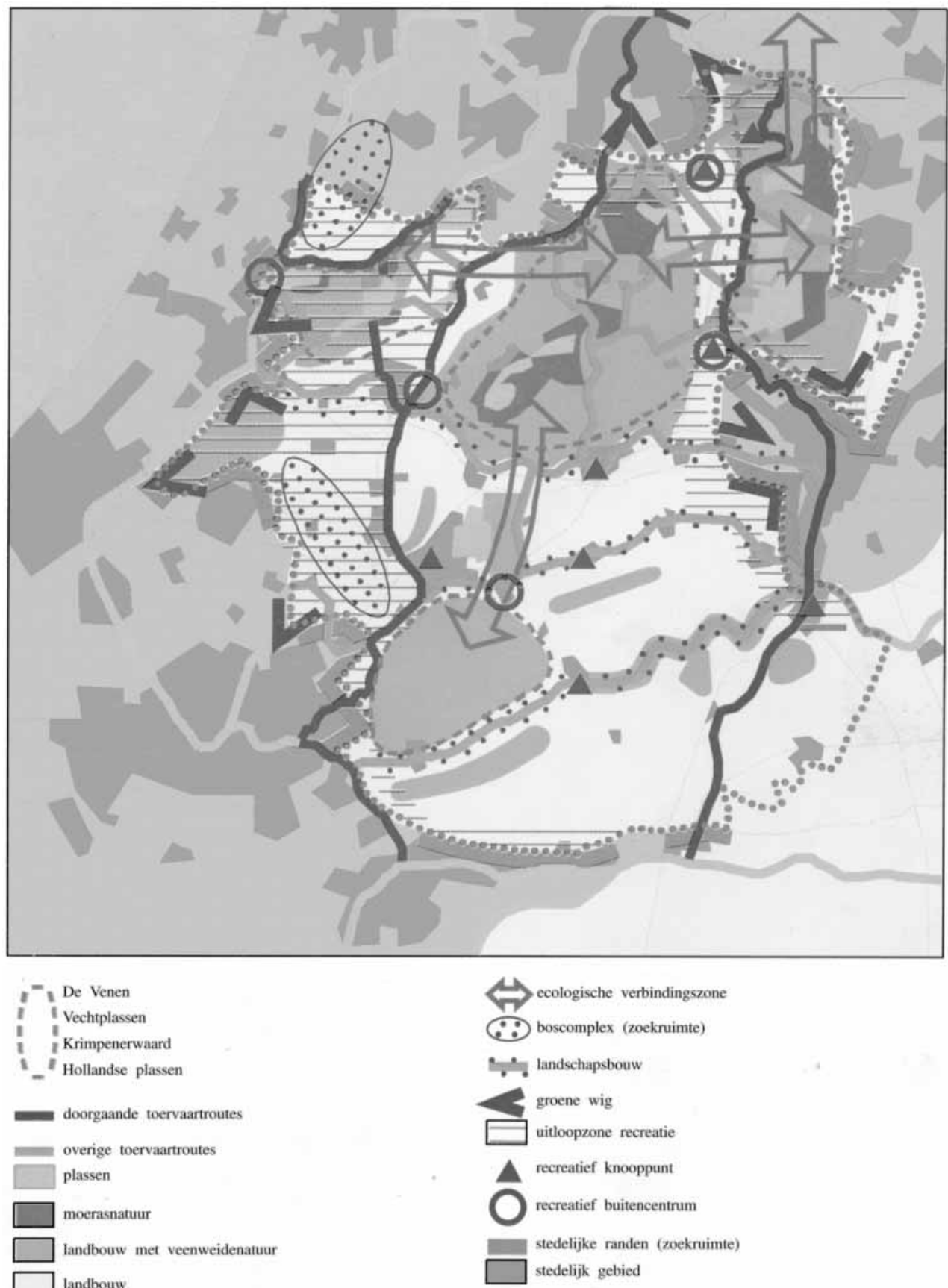

doorgaande toervaartroutes
overige toervaartroutes
plassen
$\square$ moerasnatuur
$\square$ landbouw met veenweidenatuur
$\square$ landbouw

๑oe begrenzing Groene Hart

Figure 1. The complexity of the policy discourse on the Green Heart is reflected in a multilayered image of its spatial structure (source: Stuurgroep Groene Hart, 1992). 
the Golden Triangle or the Blue Banana, which assigned an identity of centrality to certain European regions. It is interesting to note that the most outspoken spatial concept of the European Spatial Development Perspective, namely polycentricity, is not attached to any particular region, but in fact covers the whole of Europe and operates-or is intended to operate-as a unifying concept, replacing centre-periphery discourses. But it is not mapped (Waterhout, 2002)!

Naming and mapmaking at levels above the nation-state are closely related to spatial positioning. We can follow Williams (1996, page 97), who presumes that most local planners have a clear sense of location within the national space, or that for which they are responsible, but "the capacity to conceptualise or think about one's location or situation within the spatial structure of Europe as a whole is a skill which often needs to be developed." Planners positioning their country (or region) in a wider, European context often end up placing themselves in the middle of the world, an inclination acquired at a young age simply because that is precisely what school atlases do. Dutch and German planners designing European planning maps in the late 1960s did so too. The Dutch were contemplating the desired urban structure of North West Europe, placing the Netherlands in the middle and 'discovering' a megalopolis located on both sides of the North Sea. Their German colleagues made a similar map, but their vision was shifted several hundred kilometres eastwards, producing an entirely different image of the North West European urban fabric (see figure 2, over).

Before the 1990s, planning and mapmaking exercises above the level of the nationstates were incidental and confined to the North West of Europe. This situation has changed. In the 1990s representatives of EU member states together with the European Commission produced the European Spatial Development Perspective, ESDP (CEC, 1999), which I discuss below (see also Faludi and Waterhout, 2002). During the making of the ESDP, the European Commission broadened the working of the community initiative INTERREG. Adopted in 1990, INTERREG was originally designed to stimulate cross-border cooperation in relatively small areas. During the second programme period (1994-99), the geographical scope was broadened considerably, reflecting the Commission's growing involvement in European spatial planning discourse (Doucet, 2002). The INTERREG IIC Guidelines document, published in 1996, employs a transnational division of Europe as its starting point. The guidelines seek to put countries and regions together and encourage them to cooperate. There was an initial crude division of Europe by the European Commission when it was preparing the Europe 2000+ document, a study report on Europe's territorial organisation (Wise, 2000). We could argue, as Gripaios and Mangles (1993, page 746) have done, that the Commission had hoped that superregions would become a coherent economic alternative to the nation-state (see CEC, 1991, page 22). Clearly the Commission was opting for new patterns of governance based on cooperation and thereby boosting regionalism. As the European Commission (CEC, 1994, page 69) put it: "to encourage new ways of thinking about spatial prospects which are not limited by national boundaries and to stimulate a bottom-up approach to the development of links between regions." For this reason, the Commission invited the countries and regions cooperating in these transnational areas to develop spatial visions, albeit without describing what was meant by a spatial vision.

Started as a hypothesis, the idea of transnational cooperation areas continues to live on to the present day in the present INTERREG IIIB programme, the successor to IIC. The lines drawn are very different, however. At present, there is a complex overlap of INTERREG transnational regions that, according to Nadin (1998, page 285), "reflects more accurately the complex web of interregional connections than the mutually exclusive areas of Europe $2000+. "$ Whether we are dealing with 

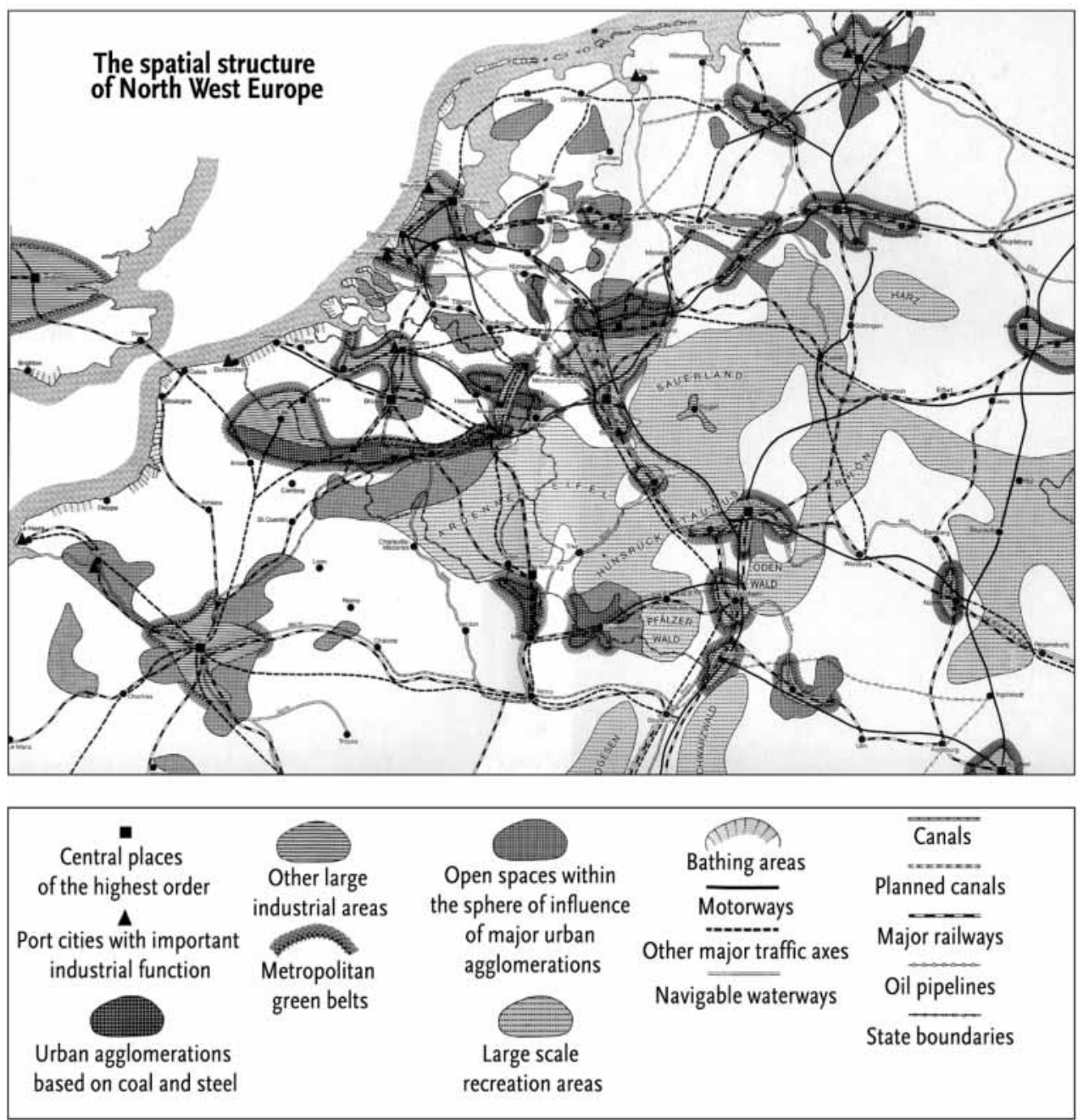

Figure 2. A German vision of the 'megalopolis' of North West Europe in the mid-1960s. Dutch planners made a similar map at about the same time, with the geographical centre located in the North Sea, suggesting a seaboard megalopolis (source: Ley, 1967).

more coherent areas than the Europe 2000/2000+ division remains to be seen. Many of the changes that have taken place since the original division of Europe into transnational study areas are the result of regions and countries positioning themselves on the European map. Nadin gives an interesting account of regions and countries positioning themselves and thereby redrawing the map on transnational superregions.

One of the original Europe 2000/2000+ study areas was the Central and Capital Cities (CCC) Area, a compact region formed by southeast England, the southern part of the Netherlands, Belgium, Luxembourg, and parts of northern France and Germany. It is in every sense the quintessential core region of Europe. When it became obvious that the transnational study areas would live on as transnational cooperation areas under the INTERREG IIC initiative, the whole of the United Kingdom and the Republic of Ireland were incorporated into the CCC Area, which had to be renamed the North West Metropolitan Area (NWMA). "This change was made primarily because of the lobbying by the Irish government who were not happy at being included 
only in the Atlantic Arc with its emphasis on peripheral and rural issues. They argued that Dublin counted as part of the metropolitan core" (Nadin, 1998, page 284; see also Nadin, 2002a; Doucet, 2002). This is an excellent example of naming, framing, spatial positioning, and, eventually, mapmaking. In the past, nobody would have dared argue that Ireland was part of the European economic core. The Blue Banana managed to 'cross' the North Sea, encompassing southeast England, but did not cross the Irish Sea. The Irish government must have thought that, if a core area could cross one sea, it could cross another. Fortuitously, as Nadin (1998) explains, the negotiation of the boundaries coincided with the Irish presidency of the EU. The cooperation area in the present INTERREG IIIB programme has become even larger and therefore even less metropolitan, diluting the influence of stakeholders interested in metropolitan policies. This resulted in a renaming of the cooperation area as North West Europe-about as neutral as a name can become.

\section{Maps as constructs}

There is still a widespread popular belief that cartography, and thus maps, reflects reality. The report on the Study Programme on European Spatial Planning illustrates this. A distinction was drawn between cartographic rationality and infographic creativity: "cartography aims at providing an objective representation of reality (in the form of maps based on data), while infography aims at giving a meaningful representation of [political] aims as interpreted by human imagination (in the form of images)" (Federal Office for Building and Regional Planning, 2001, page 129). This view is somewhat softened by the observation that cartography can also mislead, to some extent depending on the consistency of the data used as input and the methods used to transform it into a map; nevertheless, the argument remains that there are two distinct domains: one that is governed (or should be governed) by strict scientific rules and one where creativity reigns.

In his paper on framing with images, Faludi rejects the claim that the creative leap is unique to designers. He argues that any distinction drawn between the realms of design and other realms of expertise based on this are fallacious: "There is also verbal language so poetic as to stretch the mind" (1996, page 99). But there is a more fundamental issue at stake, one that has to do with objectivity claims in relation to cartography. It seems that cartography must deal with more persistent demands for objectivity than other areas. The introduction of new 'clean' technologies like the Global Positioning System or remote sensing has led some to believe that such technology could lead to a new objectivity in cartography (see Verweij and Boie, 2000, for instance). There seems to be a parallel with photography and its introduction in the 19th century, namely that photographs could show reality as it is. We now know that photography is not 'innocent' (Verweij and Boie, 2000). A photographer constantly makes decisions on focus, distance, and framing, not to mention the possibilities for manipulation in the darkroom, or on the computer.

Robbins (2001) shows us how emergent technologies like remote sensing and geographic information systems are not the impartial tools we may expect them to be. Satellite images always have to be interpreted and, in the process, one must make decisions about, for example in Robbins's case, what exactly constitutes a forest. Frames like this are inextricably linked to the institutions in which the interpreters operate, their practices and interests. In the case of forest policies in India, Robbins explains how state authorities used their power to produce outcomes that were detrimental to local farmers. Robbins calls this the hegemonic position of state-fixed categories (page 163) and speaks of the "politics of categorisation" (page 172). By fixing certain interpretations of the environment, certain forms of management are forced, 
ultimately leading to a process called reverse adaptation: existing landscapes are reengineered to suit technical means (page 175). This is perversely reminiscent of the computer term 'what you see is what you get'. As a counterstrategy Robbins advocates the creation of competing maps to break through the hegemonic practices of state institutions (page 162).

An example like this shows that all claims to objectivity are flawed. Surprisingly, some scientific disciplines have protected themselves from these insights. Postwar cartographers might have assumed a stance similar to that taken by the members of the Wiener Kreis during the interwar period (these positivists wanted to turn away from the metaphysical and theological thinking of their day, advocating instead neutral, objective systems of concepts and theories). Postwar cartographers, perhaps reacting to the horrors of geographical mapmaking, have emphasised that mapmaking should be based on concrete and reliable facts.

According to Crampton (2001), it is only fairly recently that cartography seems to have broken with the 'correspondence theory of mapping practice', based on the assumption of a direct relationship between a map and the territory it represents. But maps, as Wood (1992) points out, construct and do not reproduce the world. But, asks Wood rhetorically, "is any myth among cartographers more cherished than that of [a] map's dispassionate neutrality?" (page 22). Harvey can also be said to be highly critical of correspondence theory. This theory implies neutrality and any claim to neutrality "has at best proven to be a beguiling fiction and at worst a downright fraud" (2001, page 231). Although this statement relates to geographical knowledge in general, it is relevant to the discussion here because cartography is considered by Harvey as "a major structural pillar of all forms of geographical knowledge" (page 220). Such knowledge is assembled - and maps are similarly constructed - in different institutional settings, according to distinctive institutional requirements, cultures, and norms. This permeates through the content and representations of geographical knowledge.

Crampton, quoting the cartography theorist Harley, comes to similar conclusions: "Cartography has never been an autonomous and hermetic mode of knowledge, nor is it ever above the politics of knowledge. My key metaphor is that we should begin to deconstruct the map by challenging its assumed autonomy as a mode of representation" (Harley quoted in Crampton, 2001, page 24)). On this basis, Crampton infers that maps are social constructs. A map is not objectively 'above' or 'beyond' that which is presented; one cannot use the representation to trace back to some ultimate object, knowledge, or thought. Maps should be accepted as rhetorical devices which dismantle the arbitrary dualism of propaganda versus true maps, or scientific versus artistic maps. Crampton concludes that one emergent implication is to emphasise the importance of multiple perspectives and multiple maps: "by contrast to the communication model which identifies a single optimal map (one which communicates the ideas and knowledge of the cartographer most clearly to the map user) polysemy and multiplicity are preferred" (page 244). Certainly, if these statements hold for maps aiming to depict existing spatial reality, what can be said about mapping exercises aiming to depict a desired future? In the latter case of the realm of planning, even more sharply different conceptions of space come to the surface (see Richardson and Jensen, 2003). For this, we should return to our discussion of planning and mapmaking above the national level where new 'cartographic identities' (Harvey, 2001) have to be developed. 


\section{CRONWE: the age of innocence}

As early as the 1950s, a small group of planners from various European countries and regions brought together under the umbrella of the permanent Conference of Regions in North West Europe (CRONWE), started to analyse and conceptualise 'their' area. Although this was a small portion of the present EU, in those days it was planning on an unprecedented scale (Faludi and Waterhout, 2002, page 2; Fit and Kragt, 1994; Klerkx, 1998). Advocating planning at the transnational level and identifying the recently formed European Economic Community as the appropriate planning subject, the aim of these planners was to grasp the complexities of large-scale areas. In so doing, they employed a mixture of basic scientific analysis - according to the methodological rules of the time-and political goal setting. As a link between these two domains they developed a series of maps and various spatial concepts. The efforts of the CRONWE members to identify spatial planning as one of the tasks of the European Economic Community in the EC Treaty - the Dutch planners were particularly keen to convince their national government of this - were totally unsuccessful. Undeterred, the CRONWE members used their organisation, established around 1955, as a proxy for a genuine European planning subject, and they did what they thought such a planning subject should do: study the spatial structure of Europe, set down the results in maps, and develop principles for sound spatial development. The fact that they did so in complete disregard of political sensitivities demonstrates the level of their naivety in these matters. The members of CRONWE were all planning professionals, with the majority working in government departments. They were experts, sharing common values to such a degree that one can, without much effort, derive a clear programme from their writings and mapping activities (Klerkx, 1998, page 135). The fact that they did not do this themselves is itself a sign of their communality.

The 1960s were the heyday of CRONWE (they were superseded in the 1970s by the Council of Europe). CRONWE showed that it was possible to look at the North West European area and arrive at images of spatial structures without focusing on national borders. Series of maps were made on such subjects as river-catchment areas, infrastructure, and, above all, urban structure and population distribution. Subjects such as these (the natural environment, for example) demonstrated that political borders are either irrelevant or should be tackled through cross-border cooperation.

Although CRONWE members touched on almost every possible subject, they were overwhelmingly focused on the course of urbanisation-that is, the spread of urban functions over an ever-larger area. They were very apprehensive about this development, fearing a loss of open areas. They also assumed that city dwellers would feel uncomfortable living in vast cities. Hence they advocated a contained form of urbanisation: cities and urban regions should be surrounded and 'veined' by green open spaces. Although the concept of the megalopolis was used to describe the future, the North West European megacity was thought to be formed by numerous freestanding 'urban villages'. This concept was common at that time. What CRONWE members were in fact doing was nothing less than scaling up national and regional plans to the level of North West Europe. For instance, the key of the main policy map of the Dutch Second Report on Spatial Planning from 1966 is almost identical to that on the maps of the desired urban structure of North West Europe. These images, developed around 1967/68, were in fact genuine comprehensive blueprints of the desired spatial organisation of North West Europe. Nowadays, urban form and therefore land use are seen as subjects belonging to the exclusive authorities of national and local government and not to be touched by transnational and European cooperative activity, apart from giving broad guidelines in the form of general and 
generic principles of best practices. But the 'pioneers' of CRONWE saw no difference between the regional and the transnational level. So, unfettered by institutional constraints, their planning and cartographic ambitions were great indeed. The underlying conceptions of space and spatial organisations nevertheless were on the whole traditional, based largely on a distinction between urban and rural areas and mixed with, among other things, central place theory.

\section{Benelux: an exercise in framing}

In 1986 Benelux produced the first genuine transnational planning document in Europe. The Benelux Structural Outline was developed by a very small group of representatives from the appropriate ministries. De Vries (2002, page $163 \mathrm{f}$ ) concludes that the planning process associated with this Outline was rather insular, leading to a plan without a vision at the Benelux level. The content of the plan was merely a projection of regional spatial planning concepts at the transnational level, largely mirroring contemporary Dutch spatial planning. The Outline was accompanied by a single map, which was in fact an enlargement of the policy map of the Dutch Third Memorandum on Spatial Planning (the 1976 Urbanisation Report). An anecdote about spatial planning and cartography on the transnational level reveals much about the production of this map. When the Outline map was almost complete, there was an outcry from the representatives from the Walloon Region. The spatial categories included on the policy map were all larger urban units, being a reflection of the Dutch urbanisation pattern and Dutch spatial planning policy. Because of this mapping technique (excluding the Walloon industrial axis running from Mons to Liège), the entire Walloon Region looked virtually unpopulated, a true désert Wallone. Consequently, a new policy category had to be mapped out on the run, namely 'centres in rural areas', to produce a slightly different image. Nevertheless, we can say that the conceptions of space underlying this Outline are fairly traditional and comparable with those of the CRONWE planners. Maintaining a clear distinction between an urban and a rural realm was a main objective of the Outline. The map accompanying the document shows an orderly urbanisation pattern made up of clearly recognisable, freestanding cities and urban regions: a planner's dream.

Quite soon afterwards, at the end of the 1980s, the Outline was felt to be deficient in its analysis of the interrelationships between the various constituent parts of Benelux. The Outline was also considered outdated and lacking in commitment. In 1994, the planning ministers of two countries (the Netherlands and Luxembourg) and three regions (Flanders, the Brussels Capital Region, and Wallonia, reflecting the fact that spatial planning in Belgium is federalised and that all sovereign powers, including those entering into international planning agreements, are vested in the regions) embarked on the joint preparation of a Second Structural Outline for Benelux.

The preparation of the Second Outline was markedly different from that of its predecessor. The working model was chosen with great care. The preferred option was to form a planning group or 'project team' consisting of delegates who had the ear of the five national and regional planning agencies. The obvious alternative would have been to commission a consortium of advisors. The reason for rejecting this option was the importance attached to assembling people from the five diverse planning cultures within the planning group in order to incorporate the diversity that existed within Benelux in the process (Zonneveld and Faludi, 1997, page 10).

Framing proved to be one of the main elements of the new Outline, both internally (that is, within the project team), and externally (that is, the Second Outline appealing to the broader policy context). Initially, the five ministers responsible for Benelux cooperation determined that the work should focus on a limited number of 
sectoral topics. However, it soon became clear that an initial investment was needed to develop a common frame. The various members of the planning group decided to exchange insights into their respective planning systems and cultures, resulting in an analysis of planning documents, the drafting of relevant legislation, and so on. A related aspect was the investment in developing a common planning terminology. This was far from easy, because the terminology had to 'fit' both the two main languages spoken in Benelux: French and Dutch (although Flemish planning terminology differs in a few respects from Dutch). The significance of this approach may be gathered from an examination of the Second Outline: the end product of the internal framing exercise, the Conceptual Frame, comprises an integral part of the document (Zonneveld and Faludi, 1997, page 11).

The frame of the Second Outline consists of three elements: a 'basic philosophy' ('sustainability', 'diversity', and 'coherence'), a 'vision of the desired spatial development' (the purpose of which was to distil the principles of the basic philosophy into concrete policy statements), and a 'concept of the desired spatial structure'. The concept reflects the spatial structural principle verbally and visually (see Van den Broeck, 1997). In this case, cartography and mapping are only part of the third element, the concept, whereas in the present scientific debate on spatial visions (for instance, Jensen and Richardson, 2001) the term relates to all three elements. Be that as it may, the main controversies involving the content of the Second Outline all relate to the level of the 'concept' and its cartography. It is interesting to note that the makers of the Second Outline have tried to incorporate new conceptions of space, in particular exploring emerging spatial relationships in contrast with the static vision of the 1986 Outline. One of the conceptual proposals was a north-south chain of urban networks (see figure 3, over), formed by the Randstad, the Flemish Diamond, the Brussels metropolitan area, and the Walloon Central Area (Brussels - Mons - Charleroi-Namur). The rationale behind this stemmed from the observation that in none of the participating countries and regions was there an awareness that, if one looks at the competitive position of Benelux in its entirety, the most competitive urban regions in each of the countries and regions form a kind of chain. The proposal was certainly not to develop this chain as some sort of megalinear city or corridor, but to support the urban regions when it comes to, for instance, instruments to improve the qualities of the business environment. In each of the countries and regions, arguments were put forward to reject the north-south chain, particularly because the concept allegedly undervalued important east-west relationships. The reactions in the Walloon Region after the publication of the Second Outline were particularly fierce. According to some politicians and administrators, the Second Outline branded the Walloon Region as a kind of 'Indian reservation', failing to pay adequate attention to the various characteristics of space and place in this region.

Following the publication of the Second Outline, approval was sought through a consultation process between the ministers. During the discussions, it became obvious that the Second Outline had to be revised and some of the maps redrawn. The north - south chain of urban networks was diluted, and the idea of a European Green Heart, encompassing parts of the Walloon Region, Luxembourg, and areas across the borders with Germany and France, was abandoned altogether (De Vries, 2002, page 215). Furthermore, all the maps were taken out of the main text of the Second Outline and relegated to an appendix. This case exemplifies the sensitivities involved in mapmaking and spatial positioning. 


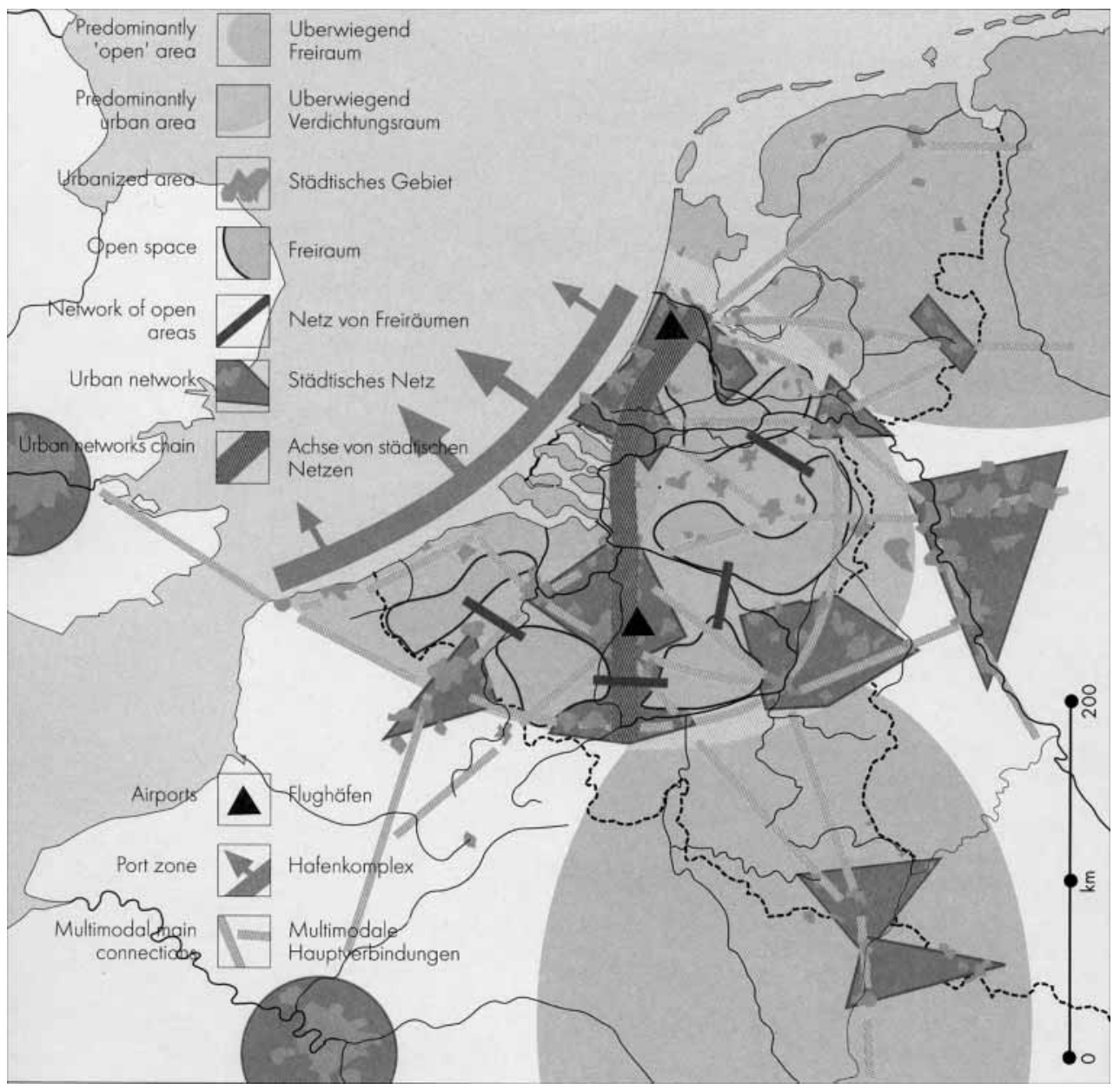

Figure 3. A novel vision of the spatial structure of Benelux, including a large-scale chain of urban networks and a 'green heart' (lower right). Both perceptions met a great deal of resistance and were removed from the maps of the final Benelux policy document (image drawn from an information brochure published by the Secretariat-General of the Benelux Economic Union in 1996).

\section{NWE's spatial vision: hegemonic discourse?}

Many other transnational and cross-border projects that promote cooperation in the field of spatial planning also reveal the politically sensitive nature of developing spatial concepts and translating them into maps. A clear example is given by the effort-an INTERREG IIC project - to arrive at a spatial vision for the North Sea Region (one of the neighbouring regions of the North Western Metropolitan Area). In this case, the vision basically comprises ten vision statements, mere verbal expressions of goals with a spatial dimension (Spatial Vision Working Group, 2000, pages 8-9). Although drafting 'NorVision' can be described as an exercise in common language building, it is striking that spatial concepts, often appearing as iconographic metaphors' as Alexander describes them, are not part of the NorVision document. The only exceptions to this are concepts already politically legitimised by their insertion in the European Spatial Development Perspective, with 'balanced competitiveness' and 'polycentrism' the main examples (Jensen and Richardson, 2001). The 'designers' of 
NorVision very much wanted to avoid the accusation of having made a master plan, as illustrated below by the manager of the NorVision project:

"It was considered that a perspective, giving verbal guidelines for future spatial planning and development would be more suitable and would make it more acceptable for national and regional politicians and authorities as no fixed picture was given. Instead they are given directions of development, a development they themselves may design within the framework given by the perspective. As such a perspective was considered to be more open for local interpretation and consequently leaving more room for expressions of local identity. ... Don't we all have experiences with maps that-no matter how symbolic they may be-they are misinterpreted by local politicians (where is my city, it is not on the map, have you erased my city!!!??" (Thornæs, 2000, page 61).

Another major effort to conceptualise the structure of this part of Europe in addition to the Second Benelux Structural Outline is the Spatial Vision of North West Europe (NWMA Spatial Vision Group, 2000). The creative process behind this Spatial Vision was not fundamentally different from the process leading to the Second Benelux Structural Outline (see Nadin, 2002b). A Vision Group was formed to prepare the vision, assisted by a multinational team of consultants. The 'vision process' involved an analysis of North West Europe's spatial characteristics and dynamics and an evaluation of existing national and regional policies. Nadin (page 30) explains that, although the vision process had both technical and political dimensions, the political dimension was limited to the professional judgments of the Vision Group's members. As with the Second Benelux Structural Outline, the Vision was put to the political test only after a full draft had been finalised.

As far as mapmaking is concerned, the Vision Diagram (see figure 4, over) was the main output of the Spatial Vision project. Its very title suggests the delicate nature of mapping exercises: the term 'vision' implies the policy-driven imaging of space, while 'diagram' refers to a more neutral, analytical, and descriptive unfolding of spatial characteristics. Not surprisingly, the label 'Vision Diagram' was subject to criticism in the consultation phase of the vision process. The French in particular wished to change the title to stress that the Spatial Vision is meant to serve only as a springboard for discussion (NWMA Spatial Vision Group, 2001, page 17). The French had clearly developed their own vocabulary on the matter (not long before, a great debate had taken place in France on the most appropriate spatial development perspective for the French territory). The French would probably favour a designation in terms of débat (Drewe, 2002).

According to Nadin (2002b, page 33), the Vision Diagram is not a master plan, but an agenda. It is hoped that it "begins a process of establishing a common spatial development 'identity' for North West Europe", and stimulates thinking about the international positioning of cities and regions (page 35). The Vision Diagram depicts the spatial structure of North West Europe as a system of networks and nodes. Worthy of note is the indication of numerous corridors and axes which should be strengthened and the designation of various polycentric urban regions as "counterweight global gateways and economic centres". The Flemish Diamond, combined with the Lille-Kortrijk region is designated as such, as are the West Midlands, combined with Merseyside, Leeds, and Sheffield. Although this could be linked to the assumption that the provision of adequate infrastructure is a precondition for economic development (in itself rather questionable), attention was shifted to the pattern of infrastructure in North West Europe in general and the internal and external accessibility of polynuclear urban regions in particular. 


\section{A VISION FOR NORTH WEST EUROPE}

\section{An agenda for a sustainable and balanced development}

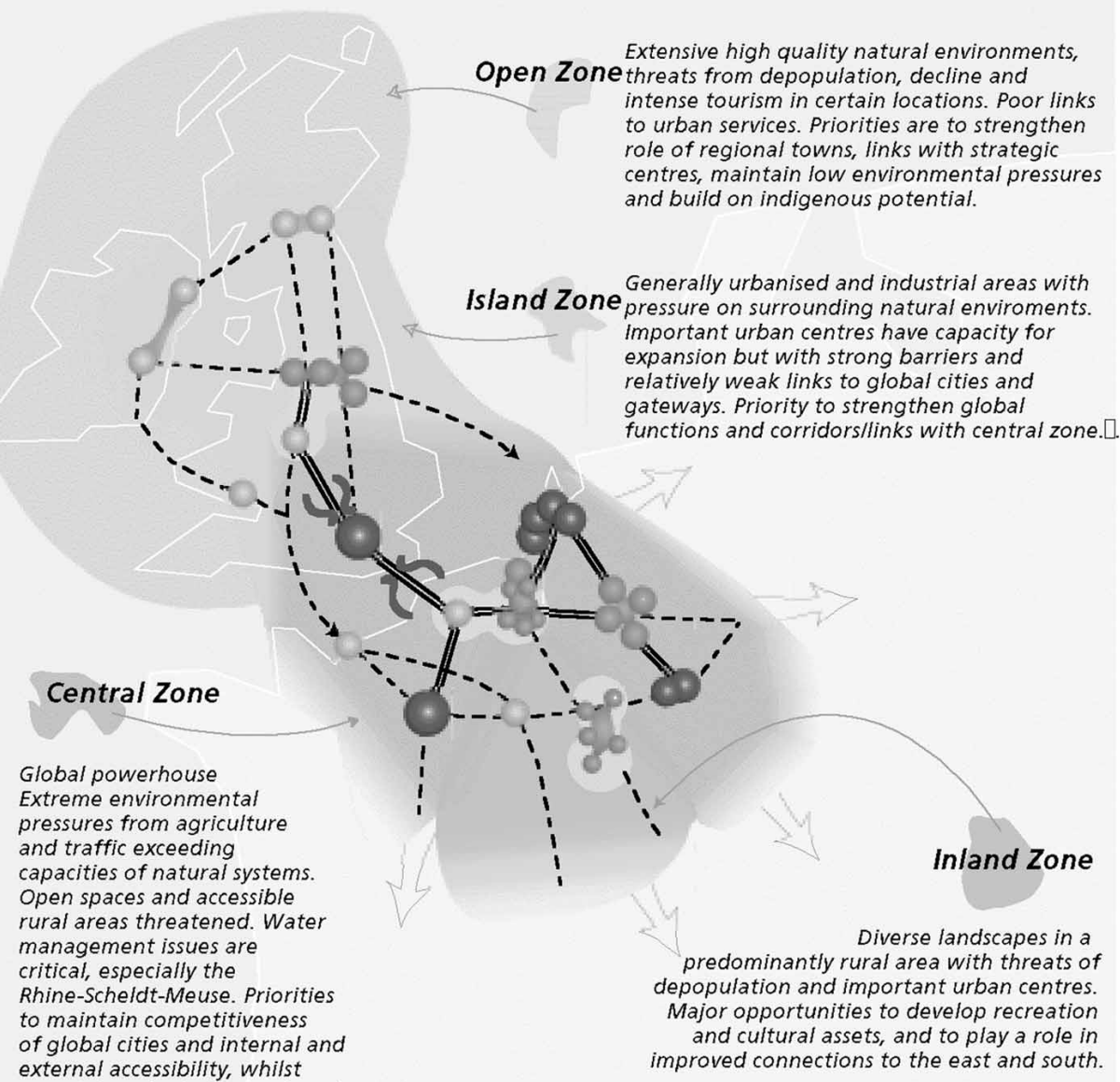

containing physical growth and

relieving pressure on environment. $\square$

Cooperation zones.

Inland Zone CentralZone Open Zone Island Zone

Global cities and gateways cities of

major economic importance for north-west Europe/rest of the world with high level of access to and from them

Strategic polycentric areas eluster of cities, high level of economic activity, key role in inward investment to north-west Europe

Strategic centres monocentric, high level economic activity, key national/regional role and focus for inward investment intense tourism in certain locations. Poor links to urban services. Priorities are to strengthen centres, maintain low environmental pressures and build on indigenous potential.

al areas with expansion but with strong barriers and gateways. Priority to strengthen global functions and corridors/links with central zone.].

Diverse landscapes in a predominantly rural area with threats of and cultural assets, and to play a role in improved connections to the east and south.

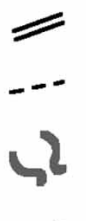

Eurocorridors.

Corridors/transport axes

to be strengthened.

Communication bottlenecks.

Enhanced external connections.

Counterweight global gateways and economic centres.

Figure 4. The Vision Diagram of the Spatial Vision for North West Europe, focusing almost exclusively on urban and infrastructure networks, emphasising the competitive position of this part of Europe, on the global scene, and on the internal distribution of economic growth areas, including new 'alternative gateways' (source: NWMA Spatial Vision Group, 2000). 
The Spatial Vision Group's Vision Diagram clearly tries to strike a balance between the strongly competitive cities and polynuclear urban regions and less competitive areas. Here we see spatial planning struggling with the idea of geographical position because this is a key method for making distinctions. Framed in this way, cities and urban regions that have a central position in Europe or North West Europe have more potential than areas in a more remote position, like Central Scotland. The counterstrategy is deceptively simple, basically entailing a plea for altering the time space of North West Europe through an improvement of the connections between, for example, Scotland and Ireland and what is referred to as the Central Zone, the metropolitan heartland of North West Europe encompassing all the capital regions. Such a choice seems obvious from a spatial planning (including infrastructure planning) point of view, because the construction and improvement of infrastructure is within the realm of control of these policy domains. Regional and economic growth effects of infrastructure and infrastructure investments are highly disputed though (for instance, see Flyvbjerg et al, 2003). There are (regional) economists claiming that other factors are far more decisive, including innovative powers (Camagni, 2001; Porter, 2001) and the organising capacity of metropolitan regions (Keating, 2001; Van den Berg et al, 1997). These nonmaterial factors are far more difficult to map if one sticks to the classic graphic language of lines, dots, and planes as the makers of the Vision Diagram obviously did.

The consultation phase that started after the publication of the first draft has led to some important considerations in terms of both the vision process and its main outcome, the Vision Diagram. To start with the vision process, the lack of consultation and cooperation with a wider range of interests was seen as a drawback by most of the respondents (NWMA Spatial Vision Group, 2001, page 7). Related to this was the comment that, in order to consider fully issues of transnational relevance, the Vision Document needs to take into account the large range of regional interests and the use of alternative scenarios to stimulate a visionary approach to the Vision exercise. Basically this means that the Vision cannot confine itself to the presentation of just one image of a desired spatial structure. The Vision Group did come to an important conclusion: the discussion arena should be widened to allow stakeholders from the regional level and nonpublic actors to participate as well. A pressing practical issue was how to avoid confrontation. One solution could be to organise the discussion at the level of smaller transnational areas than North West Europe (NWMA Spatial Vision Group, 2001, page 25).

Many of the comments made on the content of the Vision Diagram suggested that the Vision process had turned into a kind of hegemonic discourse. There was an accusation that most of the attention was focused on the metropolitan areas of the central zone (page 15). Others asserted that the urban hierarchy presented in the Vision relied too heavily on financial and economic decisionmaking powers, thereby understating the international position of some cities (page 10). The focus on the potential of cities and regions for economic development has meant that the Vision pays scant attention to the natural and cultural heritage of North West Europe (page 12). Nadin (2002a; 2002b), the leader of the consultants in the Vision process, is quite justified in saying that one of the primary functions of the Vision Diagram was to stimulate thinking about the transnational positioning of cities and regions. The question remains whether this should be done by designing and presenting a single diagram as a reflection of the maximum level of consensus that could be reached in the Vision Group. The planning process was structured in such a way that various (alternative) conceptions of space other than those within the confines of a competitiveness discourse could not reach the surface. 


\section{The ESDP: throw away the maps!}

The introduction and rejection of maps is characteristic of much of the process leading to the European Spatial Development Perspective (ESDP). The first years before the decision was taken to draft the ESDP (in Autumn 1993) were very much a period of confusion regarding the content of European spatial planning (Faludi and Waterhout, 2002, page $29 \mathrm{f}$ ). The process started in 1989 when European ministers of spatial planning met each other for the first time. Several countries, especially those from southern Europe, felt that European spatial planning should address uneven economic development in Europe. The discussion was couched in terms of an opposition between a centre located in North West Europe, and a periphery. In 1990 the Italians, chairing a ministerial meeting, gave the core new borders: a $500 \mathrm{~km}$ circle around Luxembourg. No image of this idea was ever drawn, although that could easily have been done (see Zonneveld, 2000). The other countries did not endorse this centre-periphery juxtaposition. In fact, other representatives began thinking in terms of an urban network that would cover the whole of Europe: a seamless European network without gaps.

In the following year (1991), the Dutch presidency seized the opportunity to link the concept of urban networks directly to the competitive power of big cities and spatial problems in large urban regions. A sophisticated map (see figure 5) was drawn, suggesting that the territory of Europe was highly integrated in this regard-something quite different from the general assumption of previous years that the European territory was becoming increasingly fragmented. Although this map has not been discussed, it is fair to conclude that it helped push the Myrdal-type centre-periphery juxtaposition into the background. However, the preparation of maps and cartographic representation of policy ideas would become-in the words of Williams (1996, page 112) - an issue bedevilling the whole ESDP process. In October 1993, for example, after the decision had been taken to prepare the ESDP, the German government, in preparation for their 1994 presidency, sponsored a conference to discuss the concept of a European Planning Atlas in order to promote a particular approach to European spatial planning. This idea reflects the German belief that the EU needs spatial policy concepts and guidelines. This approach did not prevail, however (Williams, 1996, pages 112, 226; 2000). When the work on the finalisation of the ESDP reached its climax (that is, the drafting of the first complete version discussed in the Netherlands in 1997), the sensitivities surrounding mapmaking also reached critical levels. As Faludi and Waterhout (2002, page 103) tell us, the maps for Part II (on spatial developments) and Part III (on policy aims and options) of the Noordwijk version of the ESDP would go further than descriptions conveying some sort of vision for the future: "Naturally though, the way in which the territories of various members states had been portrayed in the maps had drawn many comments, leading to numerous proposals to include specific features of one or more member states. It had become difficult to reduce the complexity of the maps." It became absolutely clear that "member states had different perceptions of the spatial structure of Europe and of their positions in it" (page 104). One map sought to indicate spatial obstacles to integration (Zonneveld, 2000, page 279; see also Faludi, 2000). This particular map illustrated the shape of the European territory by using a number of spatial dimensions as criteria. Because of the highly fragmented nature of the European continent when compared with Australia, for instance, inland seas like the Baltic Sea and the Mediterranean are pictured as physical barriers. Distances are also relatively great: the distance between the very north of Finland to the southern tip of Spain is about $4500 \mathrm{~km}$. What proved too controversial was an indication of the economic core areas of Europe. Whereas the southern member sates were clearly speaking in centre-periphery terms around 1990, by $1996 / 97$ this had become politically incorrect, and showing this on a map would 


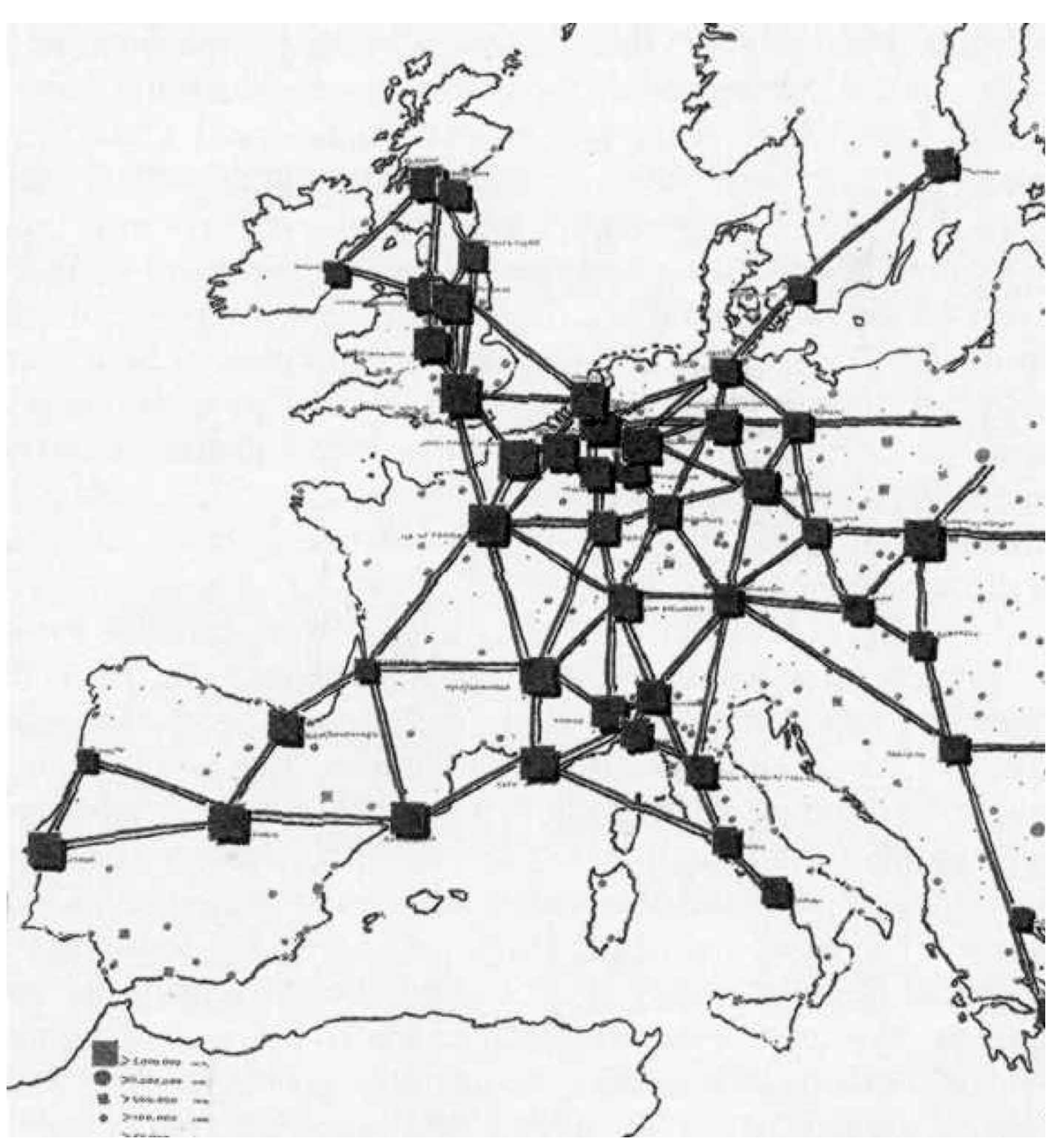

Figure 5. A map drawn by Dutch planners in the heat of some furious centre-periphery discussions, suggesting a well-integrated European territory characterised by a balanced distribution of urban growth poles (source: Minister of Housing, Physical Planning and the Environment, 1991).

implicitly stigmatise areas not belonging to the core of Europe as 'weak regions'. So the marking of the centre was removed from the map. The resulting map reappeared in the final version of the ESDP two years later (CEC, 1999, page 56), but had been altered again: all symbols used to depict physical barriers had disappeared.

Another map entitled 'territorial framework', the product of much time and energy, was withdrawn altogether (Faludi and Waterhout, 2002, page 107). This map indicated certain areas as having stronger or weaker economic structures. It also included 'major mountain areas' as a spatial category in which the qualifiers 'strong' and 'weak' were not considered applicable. However, this map proved to be too controversial. It was seen as stigmatising regions and member states outside the European core (Zonneveld, 2000, page 279). The map also depicted some sort of urban hierarchy by differentiating between international, national, and regional-level towns, cities, or urban regions. This differentiation constantly raised controversies about the indicators and principles that 
had been used. In the end, each of the four main maps of the Noordwijk version of the ESDP were moved to the appendix (Faludi and Waterhout, 2002, page 105), bearing the following disclaimer: "This representation is only an illustration of certain spatial elements referred to in the text of the 'First Official Draft' of the ESDP. ... They in no way reflect actual policy proposals and there is no guarantee that the elements displayed are exhaustive or entirely accurate" (Dutch Presidency, 1997, appendices).

In the final version of the ESDP (CEC, 1999), there is not a single map in part A on the outlines of a European spatial development policy. The visual imagery of this part is limited to icons representing each set of policy ideas on a logo suggesting the shape of Europe. And once again, as Williams (2000, page 359) tells us, the core of the EU was not mapped. Paragraph 68 refers to the core area of the EU as "the pentagon defined by the metropolises of London, Paris, Milan, Munich and Hamburg" (CEC, 1999), but no map shows this, although a strong and easily visualised spatial image is created by the text. So we have to agree with Williams that the authors of the final ESDP "found it much easier to agree on a form of words to express policy concepts [they] did to agree on cartographic representations of policy options" (2000, page 359).

Above, I mentioned the Study Programme on European Spatial Planning (SPESP) carried out after the adoption of the ESDP. One part of this SPESP was targeted at imaging. The designers commissioned by the European Commission to carry out this task were instructed not to work on maps, but on what were referred to as infographics'. The aim was to find new ways of communicating the content of the ESDP to the wider public, and not to start any controversies. The makers of the ESDP did not dare to tread where the makers of planning documents such as the Second Benelux Structural Outline or North West Europe's Spatial Vision had been prepared to go. The successor of the SPESP, the ESPON 2006 Programme (European Spatial Planning Observation Network) has as one of its aims the development of a new cartography of the European Union, including all (twelve) accession countries plus the neighbouring countries of Norway and Switzerland. There is clear pressure, from the European Programme and elsewhere, to base these maps on 'hard' and objective indicators. And although many of the maps available at the moment of writing are certainly very interesting, partly because in total twenty-nine countries are mapped instead of the usual EU15, the assumption of objective, truthful, and nonpolitical mapping is a questionable assumption underlying the entire programme.

\section{Conclusion}

In many parts of Europe, but also at the level of the European Union and the much larger level of the Council of Europe (CEMAT, 2000), the creation of spatial visions has taken off. I have not been able to deal with the full spectrum of initiatives. The fact that documents have been drafted that are either accepted on the level of government administrations or on the political level is in itself something to welcome, especially because often nothing similar exists on the national level. However, in many cases the spatial visions - I prefer this term to 'outline' or 'perspective' - lack an essential ingredient of spatial planning: maps. I should restate what Alexander said on this matter, namely that graphic representations - in this paper I have concentrated on the one category of maps - are essential for communicating ideas with a spatial dimension. Sometimes the graphic representation is restricted to general policy guidelines (the ESDP, for example), resulting in pictograms that do not relate directly to specific spatial configurations. In the case of the ESDP, all maps that were perceived as expressing some sort of evaluation of spatial characteristics were removed altogether. 
In other cases, only analytical maps were produced, giving the impression not of a vision, but of an atlas. This is the case with the spatial vision for the North Sea Region, although I do not want to suggest that such an exercise is in itself not valuable, because visioning starts with analysis (some call this 'research by design').

Sometimes just one single policy map was made, such as the first Benelux Structural Outline or the Spatial Vision - that is, the Vision Diagram - for the NWMA. Only in the case of the Second Benelux Structural Outline has a string of policy maps been produced expressing, up to a certain level, various conceptions of space.

The examples of transnational and European visioning I have discussed show many similarities. They were all produced by relatively small groups dominated by professionals. Sometimes a limited number of national, or regional, representatives participated and drafts were discussed in small steering groups. In all cases, the process has been consensus oriented, driven by the ambition to hand over to the political decisionmakers or the wider audience a single vision on either a desired spatial structure - in the case of a planning map-or a preferred spatial development, as in the case of 'infographics'. In this way, the vast spatial and political complexities at the transnational and European level were addressed by elementary vision processes and mapmaking. I would like to record here that a standard reaction of many interested parties and stakeholders was that they wished to become involved in the making of the spatial vision for a future vision exercise.

As I have argued, maps are social constructs. An absolute view of space and place does not exist. Similarly, there is no single or optimal map. The inevitable conclusion is that visioning implies multiple visioning. It is necessary to conceive visioning and mapmaking as they are: complex social and political processes that might - but not necessarily will-lead to unifying concepts and images. I would like to follow Faludi (2003, page 137) here: starting from a relativist notion of space there is nothing wrong with a plurality of visions and maps with multiple strategies for one and the same territory. Instead of striving for a single vision the aim should be to develop an array of visions and maps, each unveiling a 'reality' or a desired future. By comparing and contrasting these it becomes possible to detect and scrutinise conflicting issues instead of covering them up under a seemingly consensual spatial image (and concealing the hegemonic discourse in the process). The complexity of spatial organisation and pluricentric and multilevel decisionmaking should not be undertaken with simplified planning methods. But there is another reason why multiple visioning is something to aim for: spatial structures and spatial realities are becoming increasingly complex. Only by resorting to simple dichotomies, such as urban-rural, can one give the impression that it is still possible to visualise planning goals. However, because this distinction has been replaced by a much more complex fragmented reality, even this is an illusion (Graham and Healey, 1999). In order to grasp space and place in a graphic form one has to use a multiplicity of visual languages.

Returning to multiple visioning as a process: how could such a process be organised? What could the architecture of multiple visioning processes be? Two approaches seem promising. One is to assemble groups of stakeholders along thematic lines. Something like this seems to be happening in France at the moment under the title of Territoires 2020 (Drewe, 2002). Another approach, suggested in the NWMA Spatial Vision, is to organise groupings at the level of smaller geographical, but transnational, areas. In contrast with the NWMA Spatial Vision, I do not suggest promoting multiple visioning as a sophisticated form of consultation. If it is accepted that governance at the transnational and European level is multilevel and pluricentric, visioning cannot be confined to the realm of professionals and national administrators. Right from the start of any transnational visioning process, the arena has to be widened. 


\section{References}

Alexander E R, 2001, "Netherlands planning: the higher truth" Journal of the American Planning Association 67 91-92, $97-98$

Camagni R, 2001, "The economic role and spatial contradiction of global city-regions: the functional, cognitive, and evolutionary context”, in Global City-regions: Trends, Theory, Policy Ed. A J Scott (Oxford University Press, Oxford) pp 96-118

CEC, Commission of the European Communities (Office for Official Publications of the European Communities, Luxemburg)

1991 Europe 2000: Outlook for the Development of the Community's Territory Directorate-

General for Regional Policy

1994 Europe 2000+: Cooperation for European Territorial Development

1999 European Spatial Development Perspective: Towards Balanced and Sustainable

Development of the Territory of the EU

CEMAT, 2000 Guiding Principles for Sustainable Spatial Development of the European Continent European Conference of Ministers responsible for Regional Planning, Council of Europe, Strasbourg

Crampton J W, 2001, "Maps as social constructions: power, communication and visualisation" Progress in Human Geography 25235 - 252

De Vries J, 2002 Grenzen verkend: Internationalisering van de ruimtelijke planning in de Benelux [Exploring borders] (DUP Science, Delft)

Doucet P, 2002, "Transnational planning in the wake of the ESDP: the Northwest Europe experience", in European Spatial Planning Ed. A Faludi (Lincoln Institute of Land Policy, Cambridge, MA) pp 59-79

Drewe P, 2002, "Recente ontwikkingen in de Franse ruimtelijke ordening als inspiratiebron voor een nieuwe aanpak in Nederland" [Recent developments in French spatial planning serving as a source of inspiration for a new approach in the Netherlands], in Academische reflecties: De wetenschap aan het woord over de Vijfde Nota Rijksplanologische Dienst, Ministry of Housing, Spatial Planning and the Environment, The Hague, pp 115-125

Dutch Presidency, 1997 European Spatial Development Perspective: First Official Draft presented at the Informal Meeting of Ministers Responsible for Spatial Planning of the Member States of the European Union, Noordwijk, June; copy available from the Ministry of Housing, Spatial Planning and the Environment, The Hague

Faludi A, 1996, "Framing with images" Environment and Planning B: Planning and Design 23 $93-108$

Faludi A, 2000, "Strategic planning in Europe: institutional aspects", in The Revival of Strategic Spatial Planning Eds W Salet, A Faludi (Royal Netherlands Academy of Arts and Sciences, Amsterdam) pp $243-258$

Faludi A, 2003, "Unfinished business: European spatial planning in the 2000s", special issue on "The Application of the European Spatial Development Perspective", Ed. A Faludi Town Planning Review 74(4) 121 - 140

Faludi A, van der Valk A, 1994 Rule and Order: Dutch Planning Doctrine in the Twentieth Century (Kluwer Academic, Dordrecht)

Faludi A, Waterhout B, 2002 The Making of the European Spatial Development Perspective: No Masterplan (Routledge, London)

Federal Office for Building and Regional Planning, 2001 Study Programme on European Spatial Planning: Final Report Forschungen Heft 103.2, Federal Office for Building and Regional Planning, Bonn

Fit J, Kragt R, 1994, “The long road to European spatial planning: a matter of patience and mission" Tijdschrift voor Economische en Sociale Geografie 85461 - 465

Flyvbjerg B, Bruzelius N, Rothengatter W, 2003 Megaprojects and Risk: An Anatomy of Ambition (Cambridge University Press, Cambridge)

Graham S, Healey P, 1999, "Relational concepts of space and place: issues for planning theory and practice" European Planning Studies $7623-646$

Gripaios P, Mangles T, 1993, "An analysis of European super regions" Regional Studies 27 745-750

Harvey D, 1969 Explanation in Geography (Edward Arnold, London)

Harvey D, 2001, "Cartographic identities: geographical knowledges under globalization”, in Spaces of Capital: Towards a Critical Geography Ed. D Harvey (Edinburgh University Press, Edinburgh) pp $208-233$

Jensen O B, Richardson T, 2001, "Nested visions: new rationalities of space in European spatial planning” Regional Studies $35703-717$ 
Keating M, 2001, “Governing cities and regions: territorial restructuring in a global age", in Global City-regions: Trends, Theory, Policy Ed. A J Scott (Oxford University Press, Oxford) pp $371-390$

Klerkx E, 1998, "Plannen met Europa: Nederlandse pleidooien voor een bovennationaal ruimtelijk beleid" [Planning for Europe], MA thesis, Urban and Regional Planning, Catholic University Nijmegen, Nijmegen

Kunzmann K R, 1996, "Euro-megalopolis or themepark Europe? Scenarios for European spatial development" International Planning Studies 1143 - 163

Ley N, 1967, "Die Zukunft der Raumordnung in Nordwesteuropa" [The future of spatial planning in North West Europe], in Wegwijzers naar een goed bewoonbaar Nederland: Beschouwingen aangeboden aan Mr. J. Vink bij zijn afscheid als directeur-generaal van de Rijksplanologische Dienst (N Samsom, Alphen aan den Rijn) pp 145 - 157

Minister of Housing, Physical Planning and the Environment, 1991 Urban Networks in Europe: Third Meeting of the Ministers of the EC Member States Responsible for Physical Planning and Regional Policy (National Physical Planning Agency, The Hague)

Nadin V, 1998, "Transnational spatial planning in Europe: the role of INTERREG IIC in the UK" Regional Studies $32281-289$

Nadin V, 2002a, "Visions and visioning in European spatial planning", in European Spatial Planning Ed. A Faludi (Lincoln Institute of Land Policy, Cambridge, MA) pp 121 - 137

Nadin V, 2002b, "Transnational spatial development and planning: experience from the Spatial Vision for North West Europe", in Facing ESPON Ed. C Bengs, Nordregio Report 2002, (1) $25-40$

NWMA Spatial Vision Group, 2000 A Spatial Vision for North West Europe: Building Cooperation Ministry of Housing, Spatial Planning and the Environment, The Hague

NWMA Spatial Vision Group, 2001 Spatial Vision: Consultation Report on the Vision Document summary of responses prepared by the University of the West of England in consultation with the Lead Partner: The Ministry of Housing, Spatial Planning and the Environment, The Hague

Porter M E, 2001, "Regions and the new economics of competition", in Global City-regions: Trends, Theory, Policy Ed. A J Scott (Oxford University Press, Oxford) pp 139-157

Rein M, Schön D, 1986, "Frame-reflective policy discourse" Beleidsanalyse 15(4) 4-18

Richardson T, Jensen O B, 2003, "Linking discourse and space: towards a cultural sociology of space in analysing spatial policy discourses" Urban Studies 40 7-22

Robbins P, 2001, "Fixed categories in a portable landscape: the causes and consequences of land-cover categorization" Environment and Planning A 33161 - 179

Salet W, 2003, "Amsterdam and the north wing of the Randstad", in Metropolitan Governance and Spatial Planning Eds W Salet, A Thornley, A Kreukels (Spon, London) pp 175-188

Spatial Vision Working Group, 2000 NorVision: A Spatial Perspective for the North Sea Region Vision Working Group with representatives from spatial planning offices from the participating countries and regions, prepared by PLANCO Consulting GmbH, Essen, http://www.planco.de/ norvision.htm

Stuurgroep Groene Hart [Green Heart Steering Group], 1992 Groene Hart [Green Heart], Nadere Uitwerking Vierde nota/Plan van aanpak ROM-beleid, Eindrapport van de Stuurgroep, Ministry of Housing, Spatial Planning and the Environment, The Hague

Thornæs F, 2000, "NorVision-a spatial perspective for the North Sea Region", in Reviewing Transnational Planning Ed. F Schindegger, Austrian Institute for Regional Studies and Spatial Planning, Vienna, http://www.oir.at, pp $61-71$

Van den Berg L, Braun E, van der Meer J, 1997 Metropolitan Organising Capacity: Experiences with Organising Major Projects in European Cities (Ashgate, Aldershot, Hants)

Van den Broeck J, 1997, "The Spatial Development Perspective for the Benelux" Built Environment theme issue "Vanishing Borders: The Second Benelux Structural Outline" Eds W Zonneveld, A Faludi, 23 14-26

Van Eeten M, Roe E, 2000, "When fiction conveys truth and authority: the Netherlands Green Heart planning controversy" Journal of the American Planning Association 66 58-67

Verweij L, Boie G, 2000, "Is de cartograaf de laatste die in cartografie gelooft?: de illusie van de objectieve kaart" [Is the cartographer the last one who believes in cartography?: the illusion of the objective map] Stedebouw and Ruimtelijke Ordening 81(3) 29-33

Waterhout B, 2002, "Polycentric development: what is behind it?", in European Spatial Planning Ed. A Faludi (Lincoln Institute of Land Policy, Cambridge, MA) pp 83-103

Williams R H, 1996 European Union Spatial Policy and Planning (Paul Chapman, London) 
Williams R H, 2000, “Constructing the European Spatial Development Perspective-for whom?” European Planning Studies 8357 - 365

Wise M, 2000, "From Atlantic arc to Atlantic area: a case of subsidiarity against the regions?" Regional Studies $34865-873$

Wood D, 1992 The Power of Maps (Guilford, New York)

Zonneveld W, 2000, "Discoursive aspects of strategic planning: a deconstruction of the "balanced competitiveness' concept in European spatial planning", in The Revival of Strategic Spatial Planning Eds W Salet, A Faludi (Royal Netherlands Academy of Arts and Sciences, Amsterdam) pp $267-280$

Zonneveld W, Faludi A, 1997, "Vanishing borders: the Second Benelux Structural Outline: introduction" Built Environment theme issue "Vanishing Borders: The Second Benelux Structural Outline", Eds W Zonneveld, A Faludi 23 5-13 